\title{
Northwest Caucasus forest spreading evaluation by GIS modeling and historical and geographic data analysis
}

\author{
Nikolaj Evgen'evich Shevchenko*, Anna Petrovna Geraskina \\ Center for Forest Ecology and Productivity, Russian Academy of Sciences \\ Profsoyuznaya 84/32 St, Moscow 117485, Russian Federation \\ *e-mail: neshevchenko@gmail.com
}

Received: 13 February 2019 / Accepted: 11 March 2019

\begin{abstract}
The article presents the results of the GIS modeling of the potential areas of the Northwest Caucasus coniferous and broad leaved forest stand dominants (Abies nordmanniana, Carpinus betulus, Fagus orientalis, Picea orientalis, Quercus species). The constructed models demonstrate the significantly wider potential areas of these species as compared with the real ones and the almost complete coincidence of the potential areas of dark coniferous tree species A. nordmanniana and P. orientalis. The precipitation parameter in the driest month of the year, altitude above the sea level and temperature seasonality make the greatest contribution to the construction of GIS models of the modern area of the dark coniferous and broad leaved tree species. The analysis of the materials on the natural resource management history demonstrated that it is not the climatic changes, but the anthropogenic changes, that has been the main cause of the reduction of the area of the coniferous-broad leaved forests of the Northwest Caucasus since the middle of the 19th century. The northern boundary of the forest belt has shifted significantly from the plains and foothills to the foothill and mountain areas as a result of the economic and military development of the area.
\end{abstract}

Keywords: spatial modeling, maxent, potential area, natural resource management history, coniferous-broad leaved forests.

\section{Introduction}

The long history of anthropogenic transformation of the mountain ecosystems of the Northwest Caucasus has led to a significant deforestation of the slopes and the increase of such negative phenomena as avalanches, mudflows, rock falls, soil losses, animal and plant habitat area reduction (Mamedov, 1960; Safarov, 1982; Kazankin, 1984; Piotrovskij, 1988; Nakhutsrishvili, 2013). The wide spread of the meadow and meadow-steppe vegetation in the North Caucasus and Transcaucasia is regarded as the result of the forest clearance in the historical time (Gulisashvili et al., 1975; Kazankin, 1984). Gulisashvili (1979) points to the secondary origin of the alpine belt on the southern slope of the Greater Caucasus. According to the results of the study by Tumadzhanov (1959) and Nozhenko (1968), the birch forests of the Elbrus region are also secondary forests that have arisen in the old clearings and fires. In this regard, it has become necessary to evaluate the degree of degradation of forest ecosystems and determine the possibilities for the restoration of the lost or disturbed plant communities.

At present, there are many geobotanical criteria for evaluation of the anthropogenic changes in vegetation (Gorchakovskij et al., 2009; Hill \& Pickering, 2006; Belanovskaya \& Korotkov, 1981) which allow us for evaluating their qualitative changes. The GIS modeling computer programs, the number and introduction of which has recently grown rapidly, provide for an opportunity for quantitative assessment of anthropogenic degradation of mountain ecosystems (Elith et al., 2006; Sillero \& Tarroso, 2010). 
The purpose of the study is the evaluation of the current spread of forests in the Northwest Caucasus based on the GIS modeling data and the analysis of the data on the history of forest use in the area.

The following tasks have been formulated to achieve this goal:

1) the mapping of the potential areas of forest tree stands under the data of climatic bases and the altitude above the sea level;

2) evaluation of the influence of climatic parameters and the altitude above the sea level on the boundaries of the modern area of the dominant tree stand species

3 ) evaluation of the probably extent and causes of the reduction of the forest area of the Northwest Caucasus based on the historical and geographical data analysis.

\section{Study Area}

The study area includes the mountain and foothill parts of the North-West Caucasus (to west of Mount Elbrus). In the administrative borders these are the southern districts of the Krasnodar Krai, the Republic of Adygea and the Karachay-Cherkess Republic on the territory of the Russian Federation. The study area is within the following coordinates: in the north - about $44.8^{\circ} \mathrm{N}$, in the south $-43.5^{\circ} \mathrm{N}$, in the west $-38.5^{\circ} \mathrm{E}$, in the east $-41.5^{\circ} \mathrm{E}$. The distance from north to south is about $120 \mathrm{~km}$, and the distance from west to east is about $450 \mathrm{~km}$. According to the physiographic zoning the territory belongs to the Greater Caucasus, mostly to the Western high-mountainous province (Gvozdetsky, 1963). The basis of this area is complicated mountain structures. The first snowy peaks in the west are Mount Fisht and Oshten. In the eastern part of the study area the total height of the mountain ranges increases above 4000 meters - Mount Dombai-Ulgen (Gvozdetsky,
1963). The study area is located on the border of the temperate and subtropics zones. The climate is lukewarm. The average annual temperature is $5-7^{\circ} \mathrm{C}$, the temperature of July and August is about $15^{\circ} \mathrm{C}$, January is $4-5^{\circ} \mathrm{C}$ below zero (Makunina, 1986). The amount of precipitation varies from 500 to $3000 \mathrm{~mm}$ (Agroclimatic reference book..., 1961). In the forest belt dominate brown forest soils and humus-calcareous soils. The vegetation of the Northwest Caucasus is represented by three main zonal types - coniferous-deciduous, deciduous forests and steppes. The forests of the Northwest Caucasus are a complex set of beech forests, hornbeam forests, fir forests, pine forests, alders forests, ash and oak forests.

\section{Materials and Methods}

The data on the distribution of model tree species - tree stand dominants (Abies nordmanniana (Steven) Spach, Carpinus betulus L., Fagus orientalis Lipsky, Picea orientalis (L.) Peterm., species of the genus Quercus L.) and dark coniferous forests (Abies nordmanniana and Picea orientalis) of the Northwest Caucasus. The distribution data (Table 1) have been obtained during the expeditionary studies of the authors in the period of 2014 to 2018 in the territory of the Krasnodar Krai, the Republic of Adygea and the Karachay-Cherkess Republic.

The maps of the potential habitats of the model tree species have been created with Maxent 3.3.3k software (http://www.cs.princeton.edu/ schapire/maxent/). With the help of the color gradations, the obtained maps indicate the level of probability of finding a species at a particular point and determine the degree of influence of the environmental parameters (in \%) on the boundaries of their distribution, that is, the contribution of each factor to the model construction (Phillips et al., 2006; Phillips \& Dudik, 2008). The maximum entropy method was used to determine the potential area of the model tree species. This method and

Table 1. GIS modeling used amount of tree species finds

\begin{tabular}{|c|l|c|}
\hline No. & \multicolumn{1}{|c|}{ Species } & Amount of points \\
\hline 1. & Abies nordmanniana & 389 \\
\hline 2. & Abies and Picea & 415 \\
\hline 3. & Fagus orientalis & 847 \\
\hline 4. & Picea orientalis & 254 \\
\hline 5. & Quercus $($ Q. petraea, Q. robur and Q. hartwissiana) & 361 \\
\hline 6. & Carpinus betulus & 654 \\
\hline Total: & & $\mathbf{2 9 2 0}$ \\
\hline
\end{tabular}


its uses are described in detail in a number of publications (Phillips et al., 2006; Phillips \& Dudik, 2008, and others). The essence of the method lies in using the points of the species finding for determination of the environment characteristics that turn out to be similar for all the points of the species detection. The use of additional (climatic) databases helps to isolate the specific environmental parameters similar to the entire set of the analyzed points, and, on this basis, to identify a potential area suitable for the species distribution. Extrapolation of the probability of species finding in the analysed area is conducted for this purpose. $25 \%$ of the points were used for the resulting model testing. The sampling was carried out on the basis of the bootstrap approach. The number of the repeated replications of the model was set to 20 . The regularization multiplier was set to 2.0. The rest of the program settings were left as is by default. The cumulative format was chosen as the output format of the model values.

The quality of the models has been estimated by the AUC (area under the curve) values - area under the ROC curve representing the proportion of true and false positively classified cases (receiver operating characteristics; Fawcett, 2006) and the omission rate characterizing false negative cases (error of the second kind). The model quality is rated as excellent with the AUC values of 0.9-1; good with the $0.8-0.9$ values; very bad - if less than 0.6 ; the model accuracy corresponds to a random choice at 0.5 (Phillips \& Dudik, 2008). The visualization of the obtained GIS maps was conducted with DIVA-GIS 7.5.0 software (www.diva-gis.org) (Scheldeman \& Zonneveld, 2010).

The following layers from the WorldClim climate base (www.worldclim.org) were used in the modeling (minimum resolution -5 arc-minutes or $\sim 9 \mathrm{~km}$ per pixel) which allow for interpolation of the observed data from the years of 1950 to 2000. Climatic layers: BIO1 - average annual temperature; BIO2 - average monthly temperature; BIO3 - isothermality (BIO2/BIO7)*100); BIO4 - temperature seasonality (standard deviation *100); BIO5 - maximal temperature in the warm month; BIO6 - minimal tem- perature in the cold month; BIO7 - annual amplitude temperature (BIO5-BIO6); BIO8 - average temperature in the wettest quarter; BIO9 - average temperature in the driest quarter; BIO10 - average temperature in the warmest quarter; BIO11 - average temperature in the coldest quarter; BIO12 - amount of precipitation per year; BIO13 - amount of precipitation in the wettest month; BIO14 - amount of precipitation in the driest month; BIO15 - precipitation seasonality (coefficient of variation); BIO16 - amount of precipitation in the most humid quarter; BIO17 - amount of precipitation in the driest quarter; BIO18 - amount of precipitation in the warmest quarter; BIO19 - amount of precipitation in the coldest quarter; ALT - altitude above the sea level.

The historical and geographical information on the North Caucasus forests have been obtained from the published data and materials of the G.N. Prozritelev and G.K. Prave Stavropol State Museum-Reserve archives.

\section{Results and Discussion}

The analysis of the modeling of the areas of the potential distribution of the studied species of the coniferousbroad leaved and dark coniferous forest stand dominants of the Northwest Caucasus has provided good results of the model performance (AUC parameter) as shown in Table 2. The maps obtained from these data reliably characterize the distribution of the studied species and dark coniferous forest communities.

The results of the spatial modeling of the area of the dark coniferous communities of the Northwest Caucasus has demonstrated that the potential area of these forests in modern climatic and orographic conditions is much wider than the real one with a probability of $55-73 \%$ or more (Fig. 1). Thus, in the interfluve of the Bolshaya Laba and Kuban rivers, fir (Abies nordmanniana) and spruce (Picea orientalis) have been currently preserved only in the headwaters of the Teberda, Aksaut, Bolshoy Zelenchuk, Urup

Table 2. AUC parameter values obtained at distribution area modeling of model species and communities

\begin{tabular}{|c|l|c|c|}
\hline No. & \multicolumn{1}{|c|}{ Species/ Community } & Standard AUC data & Test AUC data \\
\hline 1. & Abies and Picea & 0.992 & 0.996 \\
\hline 2. & Abies nordmanniana & 0.992 & 0.996 \\
\hline 3. & Picea orientalis & 0.994 & 0.999 \\
\hline 4. & Quercus spp. & 0.991 & 0.995 \\
\hline 5. & Fagus orientalis & 0.990 & 0.993 \\
\hline 6. & Carpinus betulus & 0.990 & 0.994 \\
\hline
\end{tabular}


and Bolshaya Laba rivers in the range of 1500 to 2500 meters above the sea level, mainly within the boundaries of the specially protected natural areas (preserves and reserves). The potential range calculated with maxent soft- ware has shown that the range of dark coniferous species can descend below 900 meters above the sea level: the northern boundary of the potential area of these forests passes there through Psebay settlement - Peredovaya Vil-
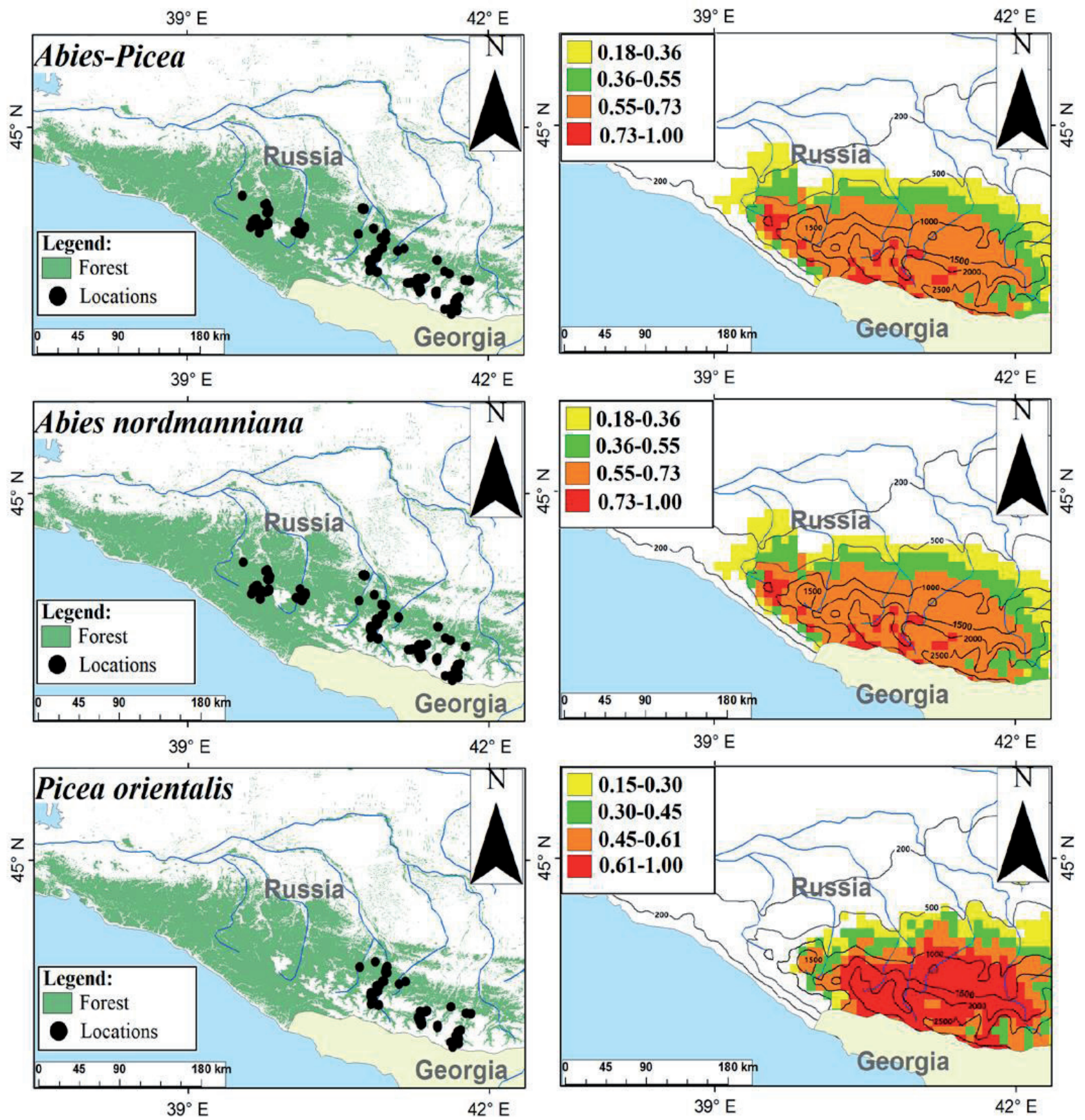

Figure 1. The real and potential area of dark coniferous forests (Abies nordmanniana and Piceae orientalis) and the area of Nordmann fir (Abies nordmanniana) and oriental spruce (Piceae orientalalis) in the Northwest Caucasus.

Note: The left column shows the maps of the location points (Locations) of the model species in the current forest borders (Forest), on the right - the potential area of model species and the contour isolines. The level of probability of finding a species at a specific point is indicated by the gradation of colors and shades. 
lage - Kardonikskaya Village - Karachayevsk Town line. Currently, the neighborhoods of the above settlements are treeless and are used for agricultural land, and the remaining adjacent forests consist only of deciduous and, less commonly, pine forests. There are several reasons for this significant difference between the potential and real area of dark coniferous forests. First, the reduction of forests for agricultural land - fields, hayfields and pastures (Klopov, 1960; Tanfiliev, 1976). Secondly, the slow recovery of fir and spruce after felling and a shortened felling turnover interval. Spruce and fir are typical late-successive species (Gigauri, 1986; Bebiya, 2002), the undergrowth growth rate in the first 10 years of life is much lower than that of the broad-leaved tree species (Orlov, 1951; Sokolov et al., 1977; Ignesti \& Paci, 1989; Bebiya, 2002), therefore, spruce and fir in the early stages of succession are inferior to the broad-leaved tree species. Under the reduced felling turnover, which was from 5 to 30 years old from the middle of the 19th century (Akinfiyev, 1893), spruce and fir have been completely expelled from the foothill areas and survived only in the mountainous areas of the upper reaches on the steep slopes inaccessible for felling.

As a result of the spatial modeling, the modern potential area of two dark coniferous tree species, A. nordmanniana and $P$. orientalis, almost completely coincided (Fig. 1). It is important to note that the modern real areas of these species have significant differences: A. nordmanniana in the Northwest Caucasus is widespread west of the eastern spruce, up to the head of the Pshekha river, and the western border of the eastern spruce area passes along the western border of the Malaya Laba river basin. According to many researchers (Kolakovsky, 1961; Sokolov et al., 1977; Bebiya, 2002; etc.), this is explained only by the ecology and biology of these species without taking into account the anthropogenic effect. In our opinion, this is primarily due to the anthropogenic effect and the ability of fir to recover faster after felling and fires. As compared to spruce, fir is better adapted to the environmental conditions (Orlov, 1951; Kolakovsky, 1961), windfalls, felling, and the fir undergrowth grows faster than the spruce undergrowth (Bebia, 2002) with the formation of different age parcels (Gigauri, 1986; Bebia, 2002), therefore, the fir has been preserved west of the Belaya river valley. The results of the spatial modeling of the potential areas of fir and spruce suggest that in the absence of the anthropogenic effect, the modern areas of fir and spruce could be not only wider, but also completely identical. This gas been indirectly confirmed by the high similarity of spruce and fir to environmental conditions (Gigauri, 1986; Bebiya, 2002; Desilets \& Houle, 2005; Nishimura, 2006).

The analysis of the contribution of climatic parameters and the altitude above the sea level to the construction of GIS models of the modern area of dark coniferous forests, spruce and fir (Table 3) has demonstrated that the amount of precipitation in the driest month (30.4-32.6\%) and the altitude of the relief above the sea level (19.1$25.3 \%$ ) make the largest contribution. Also have high rates are isothermality (6.7-13.6\%) considered as the ratio of the average temperature to the annual temperature amplitude, temperature seasonality $(8.3-12.7 \%)$ and amount of precipitation in the warmest quarter of the year (8.5-9.8\%).

Beech (Fagus orientalis) is the most common of broadleaf tree species in the Northwest Caucasus forests found in $85 \%$ of our geobotanical descriptions. Its area completely covers the area of deciduous and coniferous-broad leaved forests of the area. Oriental beech is often the dominant or codominant of plant communities. The calculated potential area of Oriental beech (Fig. 2) is significantly higher in the Northwest Caucasus only between the Bolshaya Laba and Kuban rivers where it reaches the City of Cherkessk. At present, the territory from the Karachayevsk Town - Zelenchukskaya Village - Pregradnaya Village line to the City of Cherkessk is almost completely developed for agricultural land. According to Tanfiliev (Tanfiliev, 1976), "significant areas" of forests have been destroyed from the middle of the 19th century in this territory and the remaining forests are represented only by the forests of "secondary character dominated by birch, aspen and black alder" (Tanfil'ev,

Table 3. Contribution of climate parameters to GIS model plotting of modern area of dominant tree species (\%)

\begin{tabular}{|l|c|c|c|c|c|c|c|c|c|c|}
\hline \multicolumn{1}{|c|}{ Species/community } & alt & bio2 & bio 3 & bio 4 & bio 7 & bio 11 & bio 12 & bio 14 & bio 18 & others \\
\hline Abies and Picea & 19.1 & 4.6 & 13.6 & 12.7 & 0.3 & 2.0 & 1.0 & 32.6 & 8.5 & 5.6 \\
\hline Abies nordmanniana & 19.1 & 4.6 & 13.6 & 12.7 & 0.3 & 2.0 & 1.0 & 32.6 & 8.5 & 5.6 \\
\hline Picea orientalis & 25.3 & 8.1 & 6.7 & 8.3 & 0.2 & 4.2 & 0.0 & 30.4 & 9.8 & 7.1 \\
\hline Quercus spp. & 0.2 & 0.5 & 0.5 & 27.5 & 11.1 & 8.3 & 10.3 & 26 & 0.5 & 15.0 \\
\hline Fagus orientalis & 0.3 & 2.2 & 0.5 & 22.9 & 11.2 & 10.4 & 10.9 & 25.6 & 1.5 & 14.6 \\
\hline Carpinus betulus & 0.2 & 1.2 & 0.0 & 19.1 & 21.6 & 4.2 & 10.6 & 25.3 & 0.4 & 17.3 \\
\hline
\end{tabular}


1976). The V.G. Tanfiliev assumptions on the spread of the forests with the oriental beech predominance in these areas at the beginning of the 19th century has been confirmed by a map of the potential area of the species. The border of the real and potential area has no significant differences in other parts.

Our computation have demonstrated (Table 3 ) that the precipitation amount in the driest month $(25.6 \%)$ and the
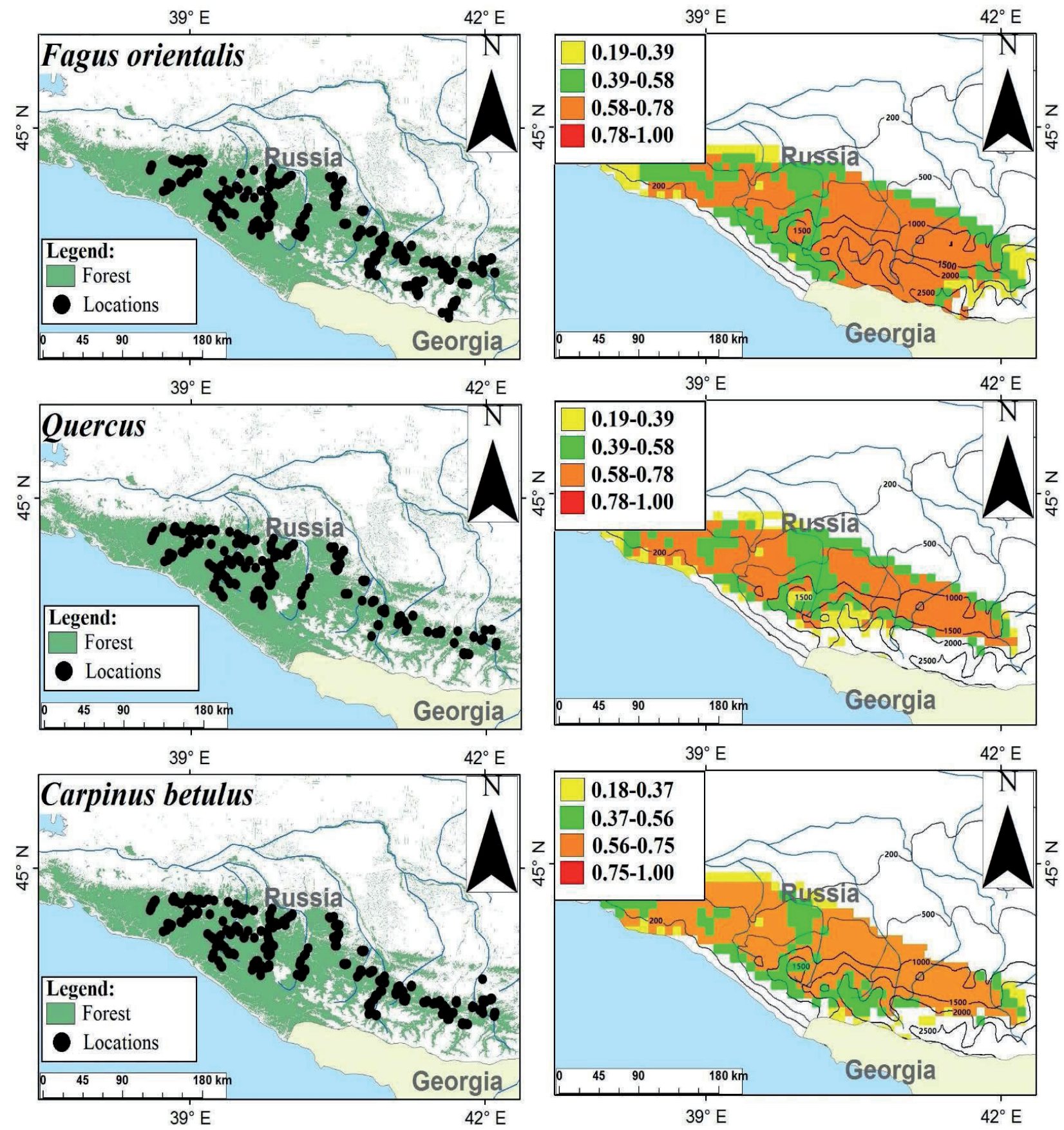

Figure 2. Real and potential area of broad leaved tree species (Fagus orientalis, Quercus spp. and Carpinus betulus) in the Northwest Caucasus.

Note: the left column indicates the maps demonstrating the locations of model species in the modern borders of forests (Forest), on the right - the potential area of model species and the isoline contour. The degree of probability of finding the species at a particular point is indicated by the gradation of colors and shades. 
temperature seasonality $(22.9 \%)$ make the greatest contribution to the plotting of GIS models of the modern oriental beech area. The annual temperature amplitude $(11.2 \%)$ and the amount of precipitation per year (10.9\%) have high rates also. The oriental beech, as well as spruce and fir, are a typical mesophyte growing in the areas where precipitation is not less than $600 \mathrm{~mm} /$ year. The root system of beech is shallow which makes this species extremely vulnerable to the moisture deficiency during the drought period (Packham et al., 2012).

The potential area species of the genus Quercus (mainly $Q$. robur and $Q$. petraea) and Carpinus betulus, that are widespread in the Northwest Caucasus forests, coincides almost completely (Fig. 2). The upper limit of distribution of these species does not exceed 2000 meters above the sea level. As a rule, these species dominate or co-dominate in the early successional post-felling forests in the foothill and lowland areas of the forest belt of the Caucasus. According to the analysis of the contribution of climatic parameters to the modern area (Table 3 ), the main limiting factors for them are: precipitation in the driest month (25.3-26\%), temperature seasonality (19.1$27.5 \%)$ and annual temperature amplitude (11.1-21.6\%). The significant contribution of the temperature regime is explained by their low frost resistance and thermophilicity (Ellenberg, 2009; Paridari et al., 2013).

Thus, evaluation of the potential distribution of the tree stand dominants of coniferous-broad leaved forests of the Northwest Caucasus through the GIS modeling suggests that the modern area of these forests and the stand dominants could be much wider. According to the longterm climate studies within the 1965-2005 period, the forest growing conditions in the area significantly improved due to an increase in the amount of precipitation: by 66 $\mathrm{mm} /$ year $(12 \%)$ in lowland areas, and by $132 \mathrm{~mm}$ (up to $17.5 \%$ ) in foothill areas (Zaurbekov, 2012). However, the forest area continued to decrease which can be explained by the anthropogenic effect (logging, forest clearance for agricultural land, fires, etc.). The evaluation of the historical and geographical materials given below, confirms this assumption.

The most massive destruction of the forests of the North Caucasus began during the Russian colonization of the region. It can be divided into two main stages: the first stage (military development stage) (the end of the 18 th century - the beginning of the 19th century) is associated with the forest clearance for military operations and the construction of fortifications; the second stage (the middle of the 19th century - the end of the 20th century) - with the stage of economic development of the region by the immigrants from the central regions of Russia and Eastern Ukraine (Sakhno-Ustimovich, 1826; Yermolov, 1868; Piotrovskij, 1988; Potto, 2006; 2008; and others).
Stage I. The urgent need for the forest clearance around fortresses for the security purposes arose at the end of the 18th century in connection with the construction of the Azov-Mozdok (Caucasian) fortification line. As the forests made it possible for the highlanders to suddenly attack military fortifications, General A.P. Yermolov developed a plan for the creation of a network of wide forest glades. From the beginning of the 19th century, the tsarist troops with the involvement of the local population cut down a considerable part of the forests along the Sunzha, Ardon, Terek, Malka, and Bolshoy Zelenchuk Rivers (Yermolov, 1868). Thus, for example, the Khankal Gorge was almost completely destroyed in 1820 due to the laying of glades from Groznaya Fortress to the military fortifications of the forest (Potto, 2006). By the beginning of 1830, wide forest glades had been laid along the Bragun - Amir-Adzhi-Yurt, Bragun - Aksai, Aksai - Gerzel line under the command of Colonel N.V. Grekov; the Mairtup forest was cut down (Sakhno-Ustimovich, 1826). The Gekhi River forests, the Malaya Chechnya forests, the Michik River forests and others had been cut down from 1840 to 1860 under the leadership of Lieutenant General R.K. Freitag (Potto, 2006). The same situation has been observed in the forests of Dagestan, KabardinoBalkaria and Karachay-Cherkessia. The mass laying of military glades in the region lasted until the beginning of the 20th century.

Stage II. The area under grain crops increased dramatically in the first half of the 19th century in the foothill and lowland areas of the North Caucasus due to the resettlement of Russian and Ukrainian peasants from the central regions of Russia and Eastern Ukraine. Large tracts of forest were replaced by agricultural fields (Potto, 2006). The immigrants had an acute need for the construction material, therefore, of course, that trade in forests increased significantly. 6320 arbas and carts of various timber products were transported through the Izvestnobrodskaya and Prokhladnenskaya Outposts for three years (from 1843 to 1845). 17916 arbas of timber were transported only through the Yekaterinogradsky Quarantine during 1847 1852; including, 13946 - by the Kabardians, 1255 - by the Ossetians, 2654 - by the Russians and Armenians. The total declared value reached more than 100 thousand rubles. (Piotrovskij, 1988).

According to Klopov (1960), the area of distribution of forests in the territory of the modern Karachay-Cherkess Republic in the late 19th-early 20th century was much wider. At present time the northern boundary of the forests here passes at the foot of the Rocky Range, not reaching the Pasture Range, then, earlier, the forests occupied not only the slopes of these ranges, but climbed to their peaks. In addition, the forests completely covered the valleys of the Bolshoy Zelenchuk and Urup Rivers and the upper reaches of the Kuban River. Deforestation 
and the centuries-old pasture of livestock led to deforestation of these territories (Klopov, 1960).

Thus, the processes of development of the North Caucasus in the 19th century led to a significant reduction in the area of forests, especially in the foothill and lowland areas. The extent of the reduction in the forest area of the North Caucasus can be estimated by interesting calculations conducted by Kazankin (1984). This author cites the data characterizing the current state of the forest cover of the basins of a number of rivers in the North Caucasus and the possible landscape forest cover. The latter implied the growth of forests to their upper climatic boundary passing along a line where the average July temperature is above $10^{\circ} \mathrm{C}$. For instance, the forests in the basins of 16 rivers of the North Caucasus with a total area of 3.650 thousand hectares presently cover 600 thousand hectares, or $16 \%$; taking into account this parameter, the forests should cover 2.003 thousand hectares, or $55 \%$ of the area of all the basins.

\section{Conclusions}

1. According to the spatial modeling, the potential area of the coniferous and broad leaved forest stand dominants of the Northwest Caucasus is significantly higher than the real range, especially in the foothill and lowland farming suitable areas. The potential modern habitats of dark coniferous tree species Abies nordmanniana and Picea orientalis completely coincide, which suggests that, in the absence of the anthropogenic effect, spruce and fir could form mixed communities within the entire area of dark coniferous forests of the Northwest Caucasus.

2. The precipitation parameter in the driest month of the year make the greatest contribution to the construction of GIS models of the modern area of the dark coniferous and broad leaved tree species of the Northwest Caucasus (Fagus orientalis, genus Quercus and Carpinus betulus species) which is explained by mesophilicity of these species and vulnerability to drought. High importance of the altitude above the sea level for the dark coniferous tree species and the importance of the temperature seasonality for broad leaved species is caused by the frost resistance of the dark coniferous tree species and the heat-loving nature of the broad leaved species.

3. The analysis of the materials on the natural resource management history demonstrated that the anthropogenic changes, and not the climatic changes, are the main cause of the reduction of the area of the coniferous-broad leaved forests of the Northwest Caucasus since the middle of the $19^{\text {th }}$ century. The northern boundary of the forest belt has shifted significantly from the plains and foothills to the foothill and mountain areas as a result of the economic and military development of the region.

\section{Acknowledgments}

The scientific materials were collected by of state assignment "Methodical approaches to the assessment of the structural organization and functioning of forest ecosystems” № AAAA-A18-118052400130-7 and results of the study were processed by supported Russian Science Foundation (project 16-17-10284).

\section{References}

Agroklimaticheskij spravochnik po Krasnodarskomu krayu, 1961 [Agroclimatic reference book to the Krasnodar Territory] Glav. upr. gidrometeorol. sluzhby pri Sovete Ministrov SSSR. Sev.-Kavkazskoe upr. gidrometsluzhby, Krasnodar: 1-466.

Akinfiev I.Ya., 1893, Severnyj Kavkaz. Botanicheskie issledovaniya [North Caucasus. Botanical research]. Tiflis: $1-56$.

Bebiya S.M., 2002, Pihtovye lesa Kavkaza [Caucasus fir forests]. MGUL, Moscow: 1-237.

Belonovskaya E.A. \& Korotkov K.O., 1981, Vliyanie cheloveka na rastitel'nyj pokrov verhovij reki Samur (Dagestanskaya ASSR) [Human influence on the vegetation cover of the upper reaches of the Samur River (Dagestan Autonomous Soviet Socialist Republic)], News of the USSR Academy of Sciences. Geographical series 4: 93-101

Desilets P. \& Houle G., 2005, Effects of resource availability and heterogeneity on the slope of the species-area curve along a floodplain-upland gradient, Journal of Vegetation Science 16: 487-496.

Elith J., Graham C.H., Anderson R.P., Dudik M., Ferrier S., Guisan A. \& Li J., 2006, Novel methods improve prediction of species' distributions from occurrence data. Ecogeography 29: 129-151.

Ellenberg H., 2009, Vegetation Ecology of Central Europe. Cambridge University Press, UK: 1-1028.

Fawcett T., 2006, An introduction to ROC analysis. Pattern Recognition Letters 27: 861-874.

Gigauri G.N., 1986, Tenevynoslivost' pihty kavkazskoj, eli vostochnoj i buka vostochnogo [Shade tolerance of Caucasian fir, Eastern spruce and Eastern beech]. Russian Journal of Forest Science 3: 50-56.

Gorchakovskij P.L. Nikonova N.I. \& Famelis T.V., 2009, Ocenka urovnya antropogennoj transformacii rastitel'nogo pokrova gornyh territorij [Assessment of the level of anthropogenic transformation of plant cover of mountain areas]. Siberian Journal of Ecology 4: 579-589.

Gulisashvili V.Z., Mahadze L.B. \& Prilipko L.I., 1975, Rastitel'nost' Kavkaza [Caucasus vegetation]. Nauka, Moscow: 1-233.

Gulisashvili V.Z., 1979, Osobennosti stroeniya gornyh lesov [Features of the structure of mountain forests] [in:]. Sini- 
cyn S.G. (ed), Mountain forests. Lesnaya promyshlennost', Moscow: 29-40.

Gvozdetsky N.A., 1963, Kavkaz. Ocherk prirody. [Caucasus. Essay of Nature]. Geografgiz, Moscow: 1-264.

Hill W. \& Pickering C.M., 2006, Vegetation associated with different walking track types in the Kosciuszko alpine area, Australia. Journal of Environmental Management 78(1): 24-34.

Ignesti S. \& M. Paci, 1989, Natural regeneration of silver fir in the Vallombrosa forest. Annali-Accademia Italiana di Scienze Forestali 38: 541-584.

Kazankin A.P., 1984, Ocenka stepeni antropogennoj degradacii gornyh ehkosistem po izmeneniyu lesistosti bassejnov rek [Assessment of the degree of anthropogenic degradation of mountain ecosystems by changing the forest cover of river basins]. Russian Journal of Ecology 6: 12-17.

Klopov A.A., 1960, Lesorazvedenie na Stavropol'e. Kratkij istoricheskij ocherk [Forestry in the Stavropol region. A brief historical essay]. Materials on the study of the Stavropol Territory 10: 21-35.

Kolakovskij A.A., 1961, Rastitel'nyj mir Kolhidy [Flora of Colchis]. MOIP, Moscow: 1-460.

Makunina A.A., 1986, Fizicheskaya geografiya gornyh regionov SSSR [Physical geography of the mountainous regions of the USSR]. MGU, Moscow: 1-166.

Mamedov T.M., 1960, Selevye potoki i lesovodstvennye mery bor'by s nimi [Mudflows and silvicultural control measures]. Goslesbumizdat, Moscow-Leningrad: 1-90.

Nakhutsrishvili G., 2013, The Vegetation of Georgia (South Caucasus). Springer, New York: 1-274.

Nishimura T.B., 2006, Successional replacement mediated by frequency and severity of wind and snow disturbances in a Picea-Abies forest. Journal of Vegetation Science 17: 57-64.

Nozhenko V.S., 1968, Tipy lesa vysokogornoj chasti Kislovodskogo leskhoza [Types of forest in the highland part of the Kislovodsk forestry]. Proceedings of the Kharkov Agricultural Institute. Lesotypological studies: 72(109): 269-274.

Orlov A.Ya., 1951, Temnohvojnye lesa Severnogo Kavkaza [Dark-coniferous Forests of the North Caucasus]. AN USSR, Moscow: 1-256.

Packham J.R., Thomas P.A., Atkinson M.D. \& Degen T., 2012, Biological Flora of the British Isles: Fagus sylvatica. Journal of Ecology 100: 1557-1608.

Paridari I.C, Jalali S.G., Sonboli A., Zarafshar M. \& Bruschi P., 2013, Leaf macro- and micro-morphological altitudinal variability of Carpinus betulus in the Hyrcanian forest (Iran). Journal of Forest Research 24: 301-307.

Phillips S.J., Anderson R.P. \& Schapire R.E., 2006, Maximum entropy modeling of species geographic distributions. Ecological Modelling 190: 231-259.
Phillips S.J. \& Dudik M., 2008, Modeling of species distributions with MAXENT: new extensions and a comprehensive evaluation. Ecography 31: 161-175.

Piotrovskij V.B. (ed.), 1988, Istoriya narodov Severnogo Kavkaza s drevnejshih vremen do konca XVIII v. [The history of the folks of the North Caucasus from ancient times to the end of the 18th century]. Nauka, Mockow: $1-554$.

Potto V.A., 2006, Kavkazskaya vojna [Caucasian war], Vol. 1. Centrpoligraf, Moscow: 1-286.

Potto V.A., 2008, Kavkazskaya vojna. Yermolovskie vremena [Caucasian war. Times of Yermolov], Vol. 2. Centrpoligraf, Moscow: 1-312.

Safarov I.S., 1982, Ohrana gornyh ehkosistem i voprosy racional'nogo prirodopol'zovaniya v Azerbajdzhanskoj SSR [Protection of mountain ecosystems and environmental management in the Azerbaijan SSR]. Russian Journal of Ecology 6: 61-63.

Sahno-Ustimovich P.M., 1826, Opisaniya chechenskogo pohoda, 1826 [From the "Description of the Chechen campaign, 1826”], [in:] A.S. Fomichev (ed.), Griboedov A.S. in the memoirs of contemporaries. Hudozhestvennaya literatura, 1980, Moscow: 122-123. (http://feb-web.ru/feb/ griboed/critics/vos80/vos122.htm?cmd=p).

Scheldeman X. \& Zonneveld M., 2010, Training manual on spatrial analysis of plant diversity and distribution. Bioversity International, Rome: 1-179.

Sillero N. \& Tarroso P., 2010, Free GIS for herpetologists: free data sources on Internet and comparison analysis of proprietary and free/open source software. Acta Herpetologica 5(1): 63-85.

Sokolov S.Ya., Svyazeva O.A. \& Kubli V.A., 1977, Arealy derev'ev i kustarnikov SSSR [Areas of trees and shrubs of the USSR], Vol.1. Nauka, Leningrad: 1-164.

Tanfil'ev V.G., 1976, Nekotorye svedeniya ob izmenenii rastitel'nosti Stavropol'ya za poslednie stoletiya [Some information about the changes in the vegetation of Stavropol over the past century]. Materials on the study of the Stavropol Territory 14: 39-45.

Tumadzhanov I.I., 1959, K istorii rastitel'nyh landshaftov zapadnoj chasti Skalistogo hrebta [To the history of plant landscapes in the western part of the Rocky Ridge]. Proceedings of the Tbilisi Botanical Institute 20: 363-410.

Yermolov A.P., 1868, Zapiski Alekseya Petrovicha Yermolova. Vol. 2. St. Petersburg: 431-432.

Zaurbekov Sh.Sh., 2012, Sovremennye klimaticheskie izmeneniya $i$ ih vliyanie na landshaftnuyu strukturu regiona (na primere Severnogo Kavkaza) [Current climate changes and their impact on the landscape structure of the region (on the example of the North Caucasus)]. Dissertation for the degree of Doctor of Geographical Sciences. Grozny State Oil Technical University, Grozny: 1-306. 